ISSN 0258-7122

Bangladesh J. Agril. Res. 35(2) : 287-296, June 2010

\title{
CROP PRODUCTIVITY AS AFFECTED BY FERTILIZER MANAGEMENT OPTIONS IN BORO -T.AMAN CROPPING PATTERN AT FARMERS'FIELDS
}

\author{
M. AKKAS ALI ${ }^{1}$, M. ROBIUL AlAM ${ }^{2}$, M.S.H. MOLLA ${ }^{3}$ \\ AND F. ISLAM ${ }^{4}$
}

\begin{abstract}
The experiment was conducted at multilocation testing (MLT) site, Sujanagar, Pabna during the year of 2003-2004 to find out a soil test based economically viable fertilizer recommendation for the cropping pattern Boro-T. aman. Six treatments viz., moderate yield goal (MYG), high yield goal (HYG), integrated plant nutrient system (IPNS), recommended fertilizer of FRG' 97 (BARC) guide (RF), farmers' practice (FP), and absolute control were employed for the study. The grain yield of Boro and T. aman rice increased 18 and 14\%, respectively, by IPNS compared to farmers' practice. Total grain yield of rice was increased by about $16 \%$ in the IPNS fertilizer package compared to farmers' practice. Fertilizer nutrients supplied both from organic and inorganic sources in adequate amount have a positive effect on productivity of soil. On an average it was found that highest grain yields of Boro rice (5.37 t/ha) and T. aman (4.49 t/ha) were obtained from integrated plant nutrient system (IPNS) where farmers' practice gave yield of 4.55 and 3.94 t/ha. The highest average gross margin (70385 Tk./ha) and marginal benefit cost ratio (3.78) was also obtained from IPNS plots.
\end{abstract}

Keywords : Crop productivity, fertilizer management, cropping pattern.

\section{Introduction}

Imbalanced use of fertilizer is a serious problem for the management of soil fertility in the country as a whole. Rice yield is low in many areas of Bangladesh, primarily due to low fertility status of soils and unbalanced use of fertilizers (Bhuiyan, 1995). Previous survey reveals that farmers of many areas of Bangladesh applied nitrogenous fertilizers higher than recommended dose for some crops. Biswas et al. (2001) reported that farmers are using more nitrogen fertilizers than others for rice, because of its visible influence on crop growth. Farmers usually use fertilizers on single crop basis without considering the whole cropping pattern, so they are not considering the residual effect of some of the nutrients on the succeeding crops. Sometimes, farmers are using higher amount of fertilizer for every crop without considering crop requirement causing imbalance in the system. Continuous degradation of soil health is caused due to imbalance use of chemical fertilizer, deadly insecticides and non-recycling of organic matter. The fertility

\footnotetext{
${ }^{1-3}$ On-rarm Research Division, Agricultural Research Station, BARI, Pabna, ${ }^{4}$ Horticulture Research Center, Bangladesh Agricultural Research Institute (BARI), Gazipur 1701, Bangladesh.
} 
status of the most of our soils is gradually deteriorating over the years (Ali et. al., 1997). Organic matter content in most of our soil is less than 2\% (BARC, 1997). Addition of organic matter along with balanced use of fertilizer might increase crop yield and restore the productivity of soil. Unless the organic matter factor is seriously considered in the cropping systems, increased yield and sustained soil productivity could not be possible (Saha et al., 1998). Generally in our country, farmers have no access to use the soil test based fertilizer management practice which has been proved to increase the grain yield of rice (Biswas et al., 2003). Therefore, it is very important to develop a cropping pattern based fertilizer recommendation under different agro-ecological zones of Bangladesh. In this context, a trial was conducted to find out the profitable and viable fertilizer recommendation for Boro-T. aman cropping pattern.

\section{Materials and Method}

The experiment was carried out at MLT site Sujanagar, Pabna, On-farm Research Division, Bangladesh Agricultural Research Institute (BARI) during the year of 2003 to 2004 in irrigated medium high land of High Ganges River Flood Plain Soil (AEZ-11). The dominant cropping pattern Boro rice-Fallow-T. aman rice was selected based on discussion with local farmers, DAE personnel and available secondary information before starting the experiment. After selecting, the site, a composite soil sample $(0-15 \mathrm{~cm}$ depth) was collected and analyzed. The analytical results indicated that the soil was alkaline having $\mathrm{pH} 8.45$, organic matter (1.78\%), total N (0.10\%), P (6.97 $\mu \mathrm{g} / \mathrm{g})$, and S $(9.78 \mu \mathrm{g} / \mathrm{g})$, and B $(0.27$ $\mu \mathrm{g} / \mathrm{g}$ of soil), Zn $(0.3 \mu \mathrm{g} / \mathrm{g}$, and $\mathrm{K}(0.39 \mathrm{meq} / 100 \mathrm{~g}$ of soil). The soil nutrient content showed that organic matter N, P, S, and B were low, Zn was very low whereas, $\mathrm{K}$ was very high. The experiment was laid out in a randomized complete block (RCB) design with six dispersed replications. Five different nutrient management packages were tested against control.

Fertilizer treatments for Boro and T.aman cropping pattern were as follow:

\begin{tabular}{|c|c|c|}
\hline \multirow{2}{*}{ Treatment } & Boro rice & T. aman rice \\
\hline & N-P-K-S-Zn-CD (kg/ha) & N-P-K-S-Zn (kg/ha) \\
\hline $\begin{aligned} \mathrm{T}_{1}= & \text { SoiI test based inorganic } \\
& \text { fertilizer dose for moderate } \\
& \text { yield goal (MYG) }\end{aligned}$ & 93 - 27-20-16-0.30-0 & $64-13-1$ 5-5-0.10 \\
\hline $\begin{aligned} \mathrm{T}_{2}= & \text { Soil test based inorganic } \\
& \text { fertilizer dose for high yield } \\
& \text { goal (HYG) }\end{aligned}$ & $131-38-20-22-0.40-0$ & $87-16-15-7-0.15$ \\
\hline $\begin{aligned} \mathrm{T}_{3}= & \text { Integrated plant nutrition } \\
& \text { system for HYG (IPNS) }\end{aligned}$ & $116-33-5-22-0.40-5000$ & $87-16-15-7-0.15$ \\
\hline $\begin{aligned} \mathrm{T}_{4}= & \text { Recommended fertilizer of } \\
& \text { FRG'97 (RF) }\end{aligned}$ & $100-20-35-10-1.5-0$ & $70-8-20-4-0$ \\
\hline $\mathrm{T}_{5}=$ Farmer’s practices $(\mathrm{FP})$ & $93-29-35-0-0-0$ & $113-21-29-15-0$ \\
\hline $\mathrm{T}_{6}=$ Absolute control & $0-0-0-0-0-0$ & $0-0-0-0-0$ \\
\hline
\end{tabular}


According to soil analysis data, the doses of different nutrients were calculated by using fertilizer recommendation guide 1997 (FRG'97). Fertilizer were used on the basis of whole cropping pattern during the T. aman crop and fertilizer nutrients (P, S, and Zn) were rationalized according to FRG' 97 (i.e., reduction of $\mathrm{P} 30 \%, \mathrm{~S} 50 \%$, and $\mathrm{Zn} \mathrm{50 \% ).} \mathrm{K}$ fertilizer was used as maintenance dose because $\mathrm{K}$ was very high in that soil. Well decomposed cowdung (CD) was used as organic source for IPNS treatment in boro season only and it contained 3, 1, and $3 \mathrm{~kg} \mathrm{~N}$, P, and $\mathrm{K} \mathrm{t}^{-1}$, respectively (Bonarup et al., 2000). Seedlings were raised on a wet nursery seedbed. Well prepared land was laid out as per treatment having six dispersed replications with unit plot size of $7 \mathrm{~m} \times 6 \mathrm{~m}$. Seedlings of 40- 45 days old boro rice (var. BRRI dhan 29) were transplanted on 16 February 27 and maintaining $20 \mathrm{~cm} \times 15 \mathrm{~cm}$ spacing and harvested on 12 and 4 June during 2003 and 2004, respectively. T. aman (var. BRRI dhan 39) was transplanted 30-35 days old seedling on 20 and 5 July maintaining same spacing as of boro and harvested on 31 and 25 October during 2003 and 2004, respectively. Fertilizers were applied as per treatments in both the seasons. Entire quantity of all fertilizers except urea were applied as basal during the final land preparation and mixed thoroughly with soil. Nitrogen fertilizer (urea) was applied as top dress in three equal splits at 15, 30, and 45 days after transplanting (DAT), respectively. Two hand weedings, were done at 30 and 50 DAT. Plant protection measures were carried out as and when required.

Table 1. Effect of different nutrient packages on yield contributing characters of Boro rice under Boro -T. aman cropping pattern during the year of 2003.

\begin{tabular}{l|l|l|l|l}
\hline \multicolumn{1}{c|}{ Treatment } & $\begin{array}{c}\text { Plant height } \\
(\mathrm{cm})\end{array}$ & $\begin{array}{c}\text { Panicles/hill } \\
(\text { no. })\end{array}$ & $\begin{array}{c}\text { Grains/panicle } \\
(\text { no. })\end{array}$ & $\begin{array}{c}\text { 1000-grain } \\
\text { weight }(\mathrm{g})\end{array}$ \\
\hline $\mathrm{T}_{1}=$ MYG & $90.8 \mathrm{a}$ & $7 \mathrm{~b}$ & $77.8 \mathrm{a}$ & $22.6 \mathrm{~b}$ \\
$\mathrm{~T}_{2}=\mathrm{HYG}$ & $94.7 \mathrm{a}$ & $10 \mathrm{a}$ & $77.5 \mathrm{a}$ & $23.3 \mathrm{a}$ \\
$\mathrm{T}_{3}=\mathrm{IPNS}$ & $94.8 \mathrm{a}$ & $10 \mathrm{a}$ & $84.3 \mathrm{a}$ & $23.6 \mathrm{a}$ \\
$\mathrm{T}_{4}=\mathrm{RF}$ & $91.7 \mathrm{a}$ & $9 \mathrm{a}$ & $80.0 \mathrm{a}$ & $22.7 \mathrm{~b}$ \\
$\mathrm{~T}_{5}=\mathrm{FP}$ & $94.5 \mathrm{a}$ & $7 \mathrm{~b}$ & $80.3 \mathrm{a}$ & $22.5 \mathrm{~b}$ \\
$\mathrm{~T}_{6}=$ Absolute Control & $69.2 \mathrm{~b}$ & $6 \mathrm{~b}$ & $57.5 \mathrm{~b}$ & $20.9 \mathrm{c}$ \\
\hline $\mathrm{CV}(\%)$ & 4 & 18 & 8 & 2 \\
\hline
\end{tabular}

Measurement of the yield components were taken from ten randomly selected rice hills located at the four sides of the sampling area of each treatment avoiding border hills. Grain and straw yields were measured $(14 \%$ moisture content) from $4 \mathrm{~m}^{2}$ sampling quadrate at the centre of each plot. Straws (harvested at ground level) were dried in the sun properly and their weight was taken from $4 \mathrm{~m}^{2}$ sampling quadrate of each plot and expressed as $\mathrm{t} / \mathrm{ha}$. 
Collected data were statistically analyzed by using MSTAT soft ware packages and mean differences for each character were compared by Duncan's New Multiple Range Test (DMRT). Cost and return analysis (partial budgeting) of different treatments were done for marginal benefit cost ratio (MBCR). Cost was counted from fertilizer only. Gross return was calculated from two years' mean yield of grain and straw.

\section{Results and Discussion}

In boro rice 2003, no significant difference was obtained in plant height among the treatments except the absolute control. Similar number of panicles/hill was observed in $T_{3}, T_{2}$, and $T_{3}$ which was significantly different from $T_{1}, T_{5}$, and $T_{6}$ treatments. Maximum number of grains/panicle was recorded in $\mathrm{T}_{3}$, which was statistically similar with the other treatments except control $\left(T_{6}\right)$. In case of 1000 grain weight, the highest weight was obtained from IPNS $\left(\mathrm{T}_{3}\right)$ treatment, which was similar with HYG $\left(\mathrm{T}_{2}\right)$ and significant difference with rest of the treatments (Table 1). In case of T. aman 2003, plant height was statistically similar among the treatments except the control. Higher panicles/hill was observed in IPNS $\left(\mathrm{T}_{3}\right)$ treatment, which was statistically similar to $T_{2}$ and $T_{1}$ and rest of the treatments were significantly different. Lowest panicles/hill was obtained in control plot. In case of grains/panicle, significant difference was not recorded among the treatments except the control. Highest 1000-grain weight was obtained from IPNS $\left(T_{3}\right)$ treatments, which was similar to HYG $\left(T_{2}\right)$ and the remaining other treatments were significantly different. Lowest grain weight was recorded from control (Table 2).

Table 2. Effect of different nutrient management packages on yield contributing characters of T. aman rice under Boro - T. aman cropping pattern during the year of 2003.

\begin{tabular}{l|l|l|l|l}
\hline \multicolumn{1}{c|}{ Treatments } & $\begin{array}{c}\text { Plant height } \\
(\mathrm{cm})\end{array}$ & $\begin{array}{c}\text { Panicles/hill } \\
(\text { no. })\end{array}$ & $\begin{array}{c}\text { Grains/panicle } \\
\text { (no.) }\end{array}$ & $\begin{array}{c}\text { 1000-grain } \\
\text { weight }(\mathrm{g})\end{array}$ \\
\hline $\mathrm{T}_{1}=$ MYG & $107.0 \mathrm{a}$ & $8 \mathrm{ab}$ & $79 \mathrm{a}$ & $23.9 \mathrm{~b}$ \\
$\mathrm{~T}_{2}=\mathrm{HYG}$ & $105.2 \mathrm{a}$ & $9 \mathrm{a}$ & $78 \mathrm{a}$ & $24.4 \mathrm{a}$ \\
$\mathrm{T}_{3}=\mathrm{IPNS}$ & $105.7 \mathrm{a}$ & $10 \mathrm{a}$ & $80 \mathrm{a}$ & $24.6 \mathrm{a}$ \\
$\mathrm{T}_{4}=\mathrm{RF}$ & $107.7 \mathrm{a}$ & $7 \mathrm{~b} \mathrm{c}$ & $80 \mathrm{a}$ & $23.7 \mathrm{bc}$ \\
$\mathrm{T}_{5}=\mathrm{FP}$ & $105.2 \mathrm{a}$ & $7 \mathrm{bc}$ & $76 \mathrm{a}$ & $23.4 \mathrm{c}$ \\
$\mathrm{T}_{6}=$ Absolute Control & $92.7 \mathrm{~b}$ & $6 \mathrm{c}$ & $63 \mathrm{~b}$ & $22.4 \mathrm{~d}$ \\
\hline $\mathrm{CV}(\%)$ & 2 & 15 & 8 & 1 \\
\hline
\end{tabular}

In case of boro rice 2004, maximum plant height was obtained from IPNS treatment, which was statistically similar to HYG whereas, lowest plant height was obtained from absolute control. In case of panicles/hill, significant difference 
was not recorded among fertilizer treatments except control. Grains/panicle was statistically similar in IPNS and HYG, which was significantly higher than other treatments. The significantly highest 1000 -grain weight was recorded from IPNS treatment, but lowest grain weight was obtained from control (Table 3). In T. aman 2004, highest plant height was recorded from farmers' practice $\left(\mathrm{T}_{5}\right)$, which was statistically similar to MYG $\left(\mathrm{T}_{1}\right)$ and rest of the treatments were significantly different. No significant difference was observed in panicles/hill among the treatments. Grains/panicle was statistically similar among the treatments except the control. No significant difference was observed in 1000-grain weight among the treatments, but the numerically higher grain weight was recorded in IPNS treatment (Table 4).

Table 3. Effect of different nutrient packages on yield contributing characters of Boro rice under Boro -T. aman cropping pattern during the year of 2004.

\begin{tabular}{l|l|l|l|l}
\hline \multicolumn{1}{c|}{ Treatments } & $\begin{array}{c}\text { Plant height } \\
(\mathrm{cm})\end{array}$ & $\begin{array}{c}\text { Panicles/hill } \\
(\text { no. })\end{array}$ & $\begin{array}{c}\text { Grains/panicle } \\
(\text { no. })\end{array}$ & $\begin{array}{c}\text { 1000-grain } \\
\text { weight (g) }\end{array}$ \\
\hline $\mathrm{T}_{1}=$ MYG & $83.7 \mathrm{~b}$ & $8 \mathrm{a}$ & $76 \mathrm{~b}$ & $20.7 \mathrm{~cd}$ \\
$\mathrm{~T}_{2}=\mathrm{HYG}$ & $87.1 \mathrm{ab}$ & $9 \mathrm{a}$ & $86 \mathrm{a}$ & $21.0 \mathrm{~b}$ \\
$\mathrm{~T}_{3}=\mathrm{IPNS}$ & $89.4 \mathrm{a}$ & $9 \mathrm{a}$ & $87 \mathrm{a}$ & $21.9 \mathrm{a}$ \\
$\mathrm{T}_{4}=\mathrm{RF}$ & $83.6 \mathrm{~b}$ & $8 \mathrm{a}$ & $69 \mathrm{~b}$ & $20.5 \mathrm{de}$ \\
$\mathrm{T}_{5}=\mathrm{FP}$ & $83.5 \mathrm{~b}$ & $8 \mathrm{a}$ & $68 \mathrm{bc}$ & $20.9 \mathrm{bc}$ \\
$\mathrm{T}_{6}=$ Absolute Control & $70.2 \mathrm{c}$ & $5 \mathrm{~b}$ & $60 \mathrm{c}$ & $20.4 \mathrm{e}$ \\
\hline CV (\%) & 12 & 4 & 10 & 5 \\
\hline
\end{tabular}

The higher grain yield (5.51 t/ha) of boro rice was obtained from IPNS treatment, which was followed by HYG and statistically lowest yield was found in absolute control in the year of 2003 (Table 5). Similar trend was also found in straw yield during 2003. In the year 2004, higher grain yield of boro rice was obtained from IPNS, which was statistically identical with all other treatments except absolute control (Table 5). The significant cumulative effect of important yield contributing characters (Tables 1 and 3) supported the yield variations in both the years. Mean grain yield of boro rice was 18\% higher in IPNS compared to farmers' practice.

During the year of 2003, grain yield of T. aman was higher in IPNS (4.72 t/ha), which was followed by HYG, MYG, and FP and the lowest yield (3.32 t/ha) was found in absolute control (Table 5). Similar trend was also found in straw yield. In the year of 2004, higher grain yield of T. aman (4.25 t/ha) was obtained from IPNS, which was statistically identical with RF, HYG and MYG, (Table 5). The lowest grain yield was obtained from absolute control. The significant cumulative effect of yield contributing characters supported higher yield (Table 2 and 4). In straw, the highest yield was obtained from IPNS and 
lowest from absolute control. The mean grain yield of $\mathrm{T}$. aman rice was increased by $14 \%$ in IPNS compared to FP. The yield response in IPNS might be due to combined effects of chemical and organic fertilizers which might have improved soil productivity and thereby increased crop yield. Yadav et al. (2000) also stated that organic manure in combination with inorganic fertilizer contributed to maintaining and enhancing the productivity of rice-wheat systems.

Table 4. Effect of different nutrient management packages on yield contributing characters of T. aman rice under Boro - T. aman cropping pattern during the year of 2004.

\begin{tabular}{l|l|l|l|l}
\hline \multicolumn{1}{c|}{ Treatments } & $\begin{array}{c}\text { Plant height } \\
(\mathrm{cm})\end{array}$ & $\begin{array}{c}\text { Panicles/hill } \\
(\text { no. })\end{array}$ & $\begin{array}{c}\text { Grains/panicle } \\
\text { (no.) }\end{array}$ & $\begin{array}{c}\text { 1000-grain } \\
\text { weight (g) }\end{array}$ \\
\hline $\mathrm{T}_{1}=$ MYG & $105.1 \mathrm{ab}$ & 7 & $71 \mathrm{ab}$ & 23.3 \\
$\mathrm{~T}_{2}=$ HYG & $103.6 \mathrm{~b}$ & 7 & $67 \mathrm{ab}$ & 23.1 \\
$\mathrm{~T}_{3}=\mathrm{IPNS}$ & $102.9 \mathrm{~b}$ & 7 & $77 \mathrm{a}$ & 23.9 \\
$\mathrm{~T}_{4}=\mathrm{RF}$ & $105.1 \mathrm{ab}$ & 6 & $67 \mathrm{ab}$ & 22.8 \\
$\mathrm{~T}_{5}=\mathrm{FP}$ & $108.6 \mathrm{a}$ & 8 & $68 \mathrm{ab}$ & 23.3 \\
$\mathrm{~T}_{6}=$ Absolute Control & $93.9 \mathrm{c}$ & 6 & $60 \mathrm{~b}$ & 23.3 \\
\hline $\mathrm{CV}(\%)$ & 3 & 14 & 15 & 4 \\
\hline
\end{tabular}

The average total grain yield of the 2 cycles of Boro-T. aman cropping pattern differed due to different nutrient management packages (Table 5). It is noteworthy that a mean total yield of $9.86 \mathrm{t} / \mathrm{ha}$ rice was possible to obtain from the pattern following fertilizer management based on IPNS, which are about $16 \%$ higher than farmers' practice and $114 \%$ higher than absolute control. Similarly, a very close result was obtained from HYG, which was increased by $11 \%$ compared to FP and 105\% higher than absolute control. Similar trend was also found in straw yield. From the above results, it was evident that the highest grain yield of boro and T. aman rice were obtained from IPNS management and it was mainly due to the positive effect of organic manuring. Similar results were also observed by On-farm Research Division in different locations (Annual Report 2001-02 and 2002-03) and Biswas et al. (2004).

These results clearly indicate that farmers used lower/higher amount of imbalance fertilizer in individual crop basis (farmers' practice) without considering the residual effect of some nutrient, nutrient requirement of crop and nutrient supplying ability of soil for sustainable yield and return.

\section{Total production of rice (based on cropping pattern)}

An increase in total production of the pattern was observed due to soil test based fertilizer management over farmer's fertilizer management. The total rice production increase (16.14\%), which was obtained in IPNS management 
followed by soil test based high yield goal (11.04\%). The lowest increase was observed in recommended fertilizer (Fig. 1). Moreover, to evaluate recommended fertilizer management (FRG' 97 guide), an additional advantage of productivity with STB fertilizer management was estimated and it was found that total production is increased by $14.92 \%$ in IPNS management followed by high yield goal (9.91\%) over recommended fertilizer management (Fig. 2).

Table 5. Effect of different nutrient management packages on the yield of Boro and T. aman under Boro-T. aman cropping pattern at MLT site, Sujanagar, Pabna during the year of 2003 and 2004.

\begin{tabular}{|c|c|c|c|c|c|c|c|}
\hline \multirow{2}{*}{ Treatment } & \multicolumn{2}{|c|}{2003} & \multicolumn{2}{|c|}{2004} & \multicolumn{2}{|c|}{ Mean } & \multirow[t]{2}{*}{ Total } \\
\hline & Boro & T. aman & Boro & T. aman & Boro & T. aman & \\
\hline \multicolumn{8}{|c|}{ Grain yield (t/ha) } \\
\hline $\mathrm{T}_{1}=\mathrm{MYG}$ & $4.23 \mathrm{~b}$ & $4.29 \mathrm{ab}$ & $4.61 \mathrm{a}$ & $3.39 a b$ & 4.42 & 3.84 & 8.26 \\
\hline $\mathrm{T}_{2}=\mathrm{HYG}$ & $5.46 \mathrm{a}$ & $4.39 \mathrm{ab}$ & $5.00 \mathrm{a}$ & $4.00 \mathrm{a}$ & 5.23 & 4.20 & 9.43 \\
\hline $\mathrm{T}_{3}=\mathrm{IPNS}$ & $5.51 \mathrm{a}$ & $4.72 \mathrm{a}$ & $5.22 \mathrm{a}$ & $4.25 \mathrm{a}$ & 5.37 & 4.49 & 9.86 \\
\hline $\mathrm{T}_{4}=\mathrm{RF}$ & $4.45 \mathrm{~b}$ & $4.03 \mathrm{~b}$ & $4.62 \mathrm{a}$ & $4.05 \mathrm{a}$ & 4.54 & 4.04 & 8.58 \\
\hline $\mathrm{T}_{5}=\mathrm{FP}$ & $4.22 \mathrm{~b}$ & $4.29 \mathrm{ab}$ & $4.88 \mathrm{a}$ & $3.58 \mathrm{~b}$ & 4.55 & 3.94 & 8.49 \\
\hline $\begin{array}{l}\mathrm{T}_{6}=\text { Absolute } \\
\text { control }\end{array}$ & $2.22 \mathrm{c}$ & 3.32 c & $1.40 \mathrm{~b}$ & $2.26 \mathrm{c}$ & 1.81 & 2.79 & 4.60 \\
\hline CV (\%) & 11.30 & 10.8 & 10.6 & 9.3 & - & - & - \\
\hline \multicolumn{8}{|c|}{ Straw yield (t/ha) } \\
\hline $\mathrm{T}_{1}=\mathrm{MYG}$ & $6.48 \mathrm{~b}$ & $6.78 \mathrm{ab}$ & $6.32 \mathrm{~b}$ & $5.00 \mathrm{~b}$ & 6.40 & 5.89 & 12.29 \\
\hline $\mathrm{T}_{2}=\mathrm{HYG}$ & $7.64 \mathrm{a}$ & $6.32 \mathrm{~b}$ & $6.55 \mathrm{ab}$ & $5.06 \mathrm{~b}$ & 7.10 & 5.69 & 12.79 \\
\hline $\mathrm{T}_{3}=\mathrm{IPNS}$ & $7.70 \mathrm{a}$ & $6.92 \mathrm{a}$ & $7.72 \mathrm{a}$ & $5.98 \mathrm{a}$ & 7.71 & 6.45 & 14.16 \\
\hline $\mathrm{T}_{4}=\mathrm{RF}$ & $6.50 \mathrm{~b}$ & $6.13 \mathrm{~b}$ & $6.23 \mathrm{~b}$ & $5.01 \mathrm{~b}$ & 6.37 & 5.57 & 11.94 \\
\hline $\mathrm{T}_{5}=\mathrm{FP}$ & $6.21 \mathrm{~b}$ & $6.71 \mathrm{ab}$ & $6.45 \mathrm{~b}$ & $5.08 \mathrm{~b}$ & 6.33 & 5.90 & 12.23 \\
\hline $\begin{array}{l}\mathrm{T}_{6}=\text { Absolute } \\
\text { control }\end{array}$ & $4.10 \mathrm{c}$ & $5.13 \mathrm{c}$ & $3.37 \mathrm{c}$ & $4.56 \mathrm{c}$ & 3.74 & 4.85 & 8.59 \\
\hline CV (\%) & 8.3 & 6.7 & 7.9 & 4.2 & - & - & - \\
\hline
\end{tabular}

\section{Nutrient uptake and apparent balance}

The uptake of $\mathrm{N}, \mathrm{P}, \mathrm{K}$, and $\mathrm{S}$ nutrient varied with the added nutrient as per the treatments and targeted crop yield of the pattern. The highest uptake was obtained from the IPNS nutrient management, which might be due to continuous supply of nutrient from the organic and inorganic combination source. From the result, it was revealed that highest uptake of nutrient enhance the total productivity of the crops. Across various treatments, there was some amount of positive apparent $\mathrm{N}$ balance except absolute control plots, these amounts were not available to the succeeding crop due to large losses through different process. 
The negative balance of $\mathrm{K}$ was attained in all the managements might be due to added lower amount in soil and higher removal by the crops from the soil. Positive balance of $\mathrm{P}$ indicated that the added amount of $\mathrm{P}$ is larger than the removal. In case of $S$, the MYG, HYG, and IPNS gave positive balance and RF and FP showed negative balance, but the reason behind this positive-negative balance is not clear to us (Table 6).

Table 6. Effect of different nutrient managements on the apparent nutrient balance in Boro- T. aman cropping pattern at MLT site Sujanagor, Pabna during the year of 2003-04 (average).

\begin{tabular}{|c|c|c|c|c|c|c|c|c|c|c|c|c|}
\hline \multirow[t]{2}{*}{$\begin{array}{c}\text { Nutrient } \\
\text { managements }\end{array}$} & \multicolumn{4}{|c|}{$\begin{array}{l}\text { Nutrient added from } \\
\text { organic and inorganic } \\
\text { sources (kg/ha) }\end{array}$} & \multicolumn{4}{|c|}{$\begin{array}{l}\text { Nutrient uptak } \\
\qquad(\mathrm{kg} / \mathrm{ha})\end{array}$} & \multicolumn{4}{|c|}{$\begin{array}{l}\text { Apparent balance } \\
\text { (kg/ha) }\end{array}$} \\
\hline & $\mathrm{N}$ & $\mathrm{P}$ & K & S & $\mathrm{N}$ & $\mathrm{P}$ & K & S & $\mathrm{N}$ & $\mathrm{P}$ & $\mathrm{K}$ & S \\
\hline $\mathrm{T}_{1}=\mathrm{MYG}$ & 157 & 40 & 35 & 21 & 149 & 25 & 140 & 15 & +8 & +15 & -105 & +6 \\
\hline $\mathrm{T}_{2}=\mathrm{HYG}$ & 218 & 54 & 35 & 29 & 170 & 28 & 160 & 17 & +48 & +26 & -125 & +12 \\
\hline $\mathrm{T}_{3}=\mathrm{IPNS}$ & 203 & 49 & 20 & 29 & 177 & 30 & 168 & 18 & +26 & +19 & -148 & +11 \\
\hline $\mathrm{T}_{4}=\mathrm{RF}$ & 170 & 28 & 55 & 14 & 154 & 26 & 146 & 16 & +16 & +2 & -91 & -2 \\
\hline $\mathrm{T}_{5}=\mathrm{FP}$ & 206 & 50 & 64 & 15 & 153 & 25 & 144 & 16 & +53 & +25 & -80 & -1 \\
\hline $\begin{array}{l}\mathrm{T}_{6}=\text { Absolute } \\
\text { control }\end{array}$ & 0 & 0 & 0 & 0 & 83 & 14 & 78 & 8 & -83 & -14 & -78 & -8 \\
\hline
\end{tabular}

'+' indicates enrichment and '-' indicates depletion or mining of nutrients.

Table 7. Mean cost and return analysis of different nutrient management packages in Boro-T. aman cropping pattern (average of 2003 and 2004).

\begin{tabular}{l|l|l|l|l}
\hline \multicolumn{1}{c|}{ Treatment } & $\begin{array}{c}\text { Gross return } \\
(\mathrm{Tk} . / \mathrm{ha})\end{array}$ & $\begin{array}{c}\text { Variable cost * } \\
(\mathrm{Tk} . / \mathrm{ha})\end{array}$ & $\begin{array}{c}\text { Gross margin } \\
(\mathrm{Tk} . / \mathrm{ha})\end{array}$ & $\begin{array}{c}\text { MBCR (Over } \\
\text { control) }\end{array}$ \\
\hline T1=MYG & 66114 & 6507 & 59607 & 3.35 \\
T2=HYG & 75073 & 7877 & 67196 & 3.73 \\
T3=IPNS & 79039 & 8654 & 70385 & 3.77 \\
T4=RF & 68329 & 6425 & 61904 & 3.75 \\
T5=FP & 67743 & 7404 & 60339 & 3.05 \\
Absolute control & 37783 & - & 37783 & - \\
\hline
\end{tabular}

*only fertilizer cost

Price of inputs (Tk./kg)

Urea $=5.5$

TSP $=13.0$

Price of out put (Tk./kg)

$\mathrm{MoP}=9.0$

Rice grain $=7.26$

Straw $=0.5$

Zupsum $=3.0$

Borax $=40.0$

Cowdung $=0.5$

$\mathrm{ZnSO} 4=50.0$ 


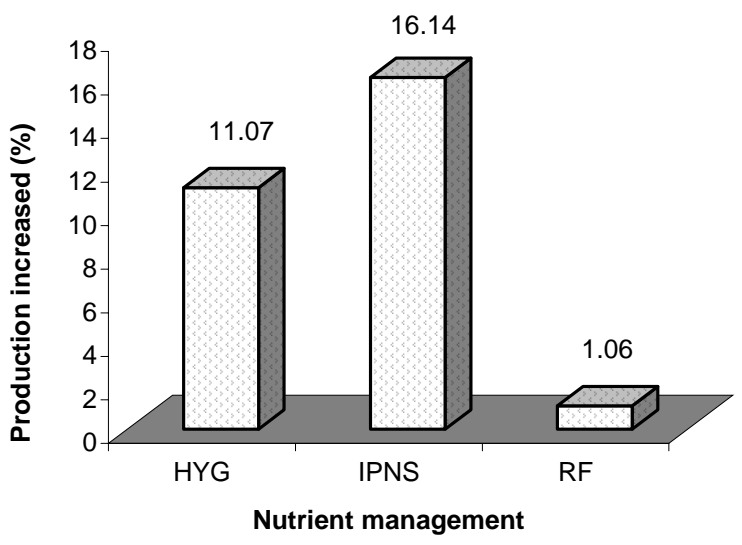

Fig. 1. Total production Boro-Fallow-T.aman cropping pattern increase duo to soil test based fertilizer packages over farmer's traditional fertilizer packages.

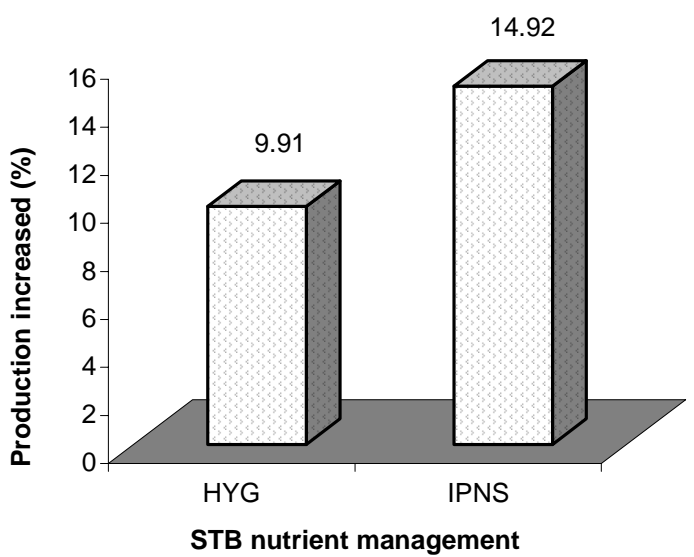

Fig. 2. Total production of the pattern increase duo to soil test based (STB) nutrient management over recommended management.

\section{Cost and return analysis}

From cost and return analysis of two cycles' results, it was found that the average highest gross return (Tk. 79039/ha) and gross margin (Tk. 70385/ha) were obtained from IPNS management, though highest variable cost was involved in this treatment (Table 7). Though lower variable cost was incurred in recommended practice and MYG, but failed to earn higher return due to lower yield of crops. IPNS treatment showed higher MBCR, but very close to RF and 
HYG, but much higher than farmers' practice. This result indicated that IPNS treatment was found economically viable as well as sustains soil health.

\section{Conclusion}

It appeared that integrated plant nutrient system (IPNS) was found economically profitable and agronomically viable due to continuous nutrient supply from inorganic and organic fertilizer sources. IPNS treatment was found more advantageous for fertilizer management which can sustain soil health. So, soil test based integrated nutrient management systems (IPNS) could be suggested for the production of Boro and T. aman crops in the cropping pattern Boro-T. aman in High Ganges River Flood Plain Soils.

\section{References}

Ali, M.M., S.M. Shaheed and D. Kabuta. 1997. Soil degradation during the period 19671995 in Bangladesh. II. Selected chemical characters. Soil Plant Nutr. 43: 870-890.

Bangladesh Agricultural Research Council, 1997. Fertilizer Recommendation Guide1997. Bangladesh Agricultural Research Council. Farmgate, Dhaka. pp 29-31.

Bonarup, N., M.A. Motalib, M.I. Haque, M.F. Islam, Y. Rayapma and P.C. Dash. 2000. Saar Suparishmala along Somonnyto Udvid Pusti Babosthapona Nirdeshika. Integrated Soil Fertility and fertilizer management Project, Department of Agricultural Extension, Farmgate, Dhaka. P 15.

Bhuyian, N.J. 1995. Intensive cropping and soil nutrient balance in Bangladesh. In: proc. Intercongress conference of commission IV on improving soil management for intensive cropping in the tropics. BARC, Dhaka, Soils Pub. No. 37. p 6 1-69.

Biswas, J.C., M.A. Saleque, M. Moniruzzaman and M.A. Sattar. 2003. Soil test based fertilizer management for rice production at farmers' field. Proc. First Annual Workshop of 1CM sub-project in northern region of Bangladesh, 5 January 2003. pp 25-30.

Biswas, J.C., M.R. Islam, S.R. Biswas and M.J. Islam. 2004. Crop productivity at farmers' fields: Options for soil test based fertilizer use and cropping patterns. Bangladesh Agron. J. 10 (1\&2): 31-41

Biswas, J.C., M.T. Ahmed and M.R. Islam. 2001. Lodging vs non-lodging in BRRI dhan 32. Bangladesh J. Train. Dev. 14: 107-113.

OFRD, BARI. 2002. Annual Research Report 2001-02. On-Farm Research Division, Bangladesh Agricultural Research Institute, Joydebpur, Gazipur pp 162-165

OFRD, BARI. 2003. Annual Research Report 2002-03. On-Farm Research Division, Bangladesh Agricultural Research Institute, Joydebpur, Gazipur.pp 20-25.

Saha, P.K., M.A. Saleque, S.K. Zaman, N.J. Bhuiyan and G.M. Panaullah. 1998. Integrated nutrient management for rice-wheat cropping systems in Old Himalayan Piedmont Plain. Progress Agric. 9 (1\&2): 163-167.

Yadav, R.L, B.S. Diwived, and P.S. Pandey. 2000. Rice-wheat cropping system: Assessment of sustainability under green manuring and chemical fertilizer inputs. Field Crops Res. 65: 15-30 